\title{
Modern pollen data from pristine taiga forest of Pechora-Ilych state nature biosphere reserve (Komi republic, Russia): first results
}

\author{
Olga V. Lisitsyna ${ }^{1 *}$, Nikolay S. Smirnov ${ }^{2,3}$, Aleksey A. Aleynikov ${ }^{4}$ \\ ${ }^{1}$ Biodiversity Unit, University of Turku, Finland; ${ }^{2}$ Pechora-Ilych state Biosphere Nature Reserve, Yaksha Village, \\ Troitsk-Pechora district, Komi Republic, 169436 Russian Federation; ${ }^{3}$ Institute of Global Climate and Ecology \\ of Roshydromet and Russian Academy of Sciences (RAS), 20B Glebovskaya str., Moscow, 107258, Russia; \\ ${ }^{4}$ Centre for Problems of Ecology and Productivity of Forests, Russian Academy of Sciences, ul. Profsoyuznaya 84/32, \\ Moscow, Russia 1179910 \\ *e-mail: olga.lisitsyna@gmail.com
}

Received: 22 April 2017/Accepted: 17 June 2017

\begin{abstract}
The first results of modern pollen investigations from western slop of Ural Mountains presented. 33 modern pollen samples have been collected in June 2016 from four dominant forest types (Sphagnum, true moss, tall fern and tall herbs sections) in Pechora-Ilych state nature biosphere reserve (Komi republic, Russia). The detail record of surrounding vegetation was performed at every sampling point. Pollen assemblages are mostly dominated by tree pollen (Betula type, Pinus haploxylon type and Picea). The pollen assemblages and vegetation records will be statistically analyzed (clustering and correspondence analysis) to investigate how vegetation is reflected in pollen assemblages and for producing new series of PPEs.
\end{abstract}

Keywords: modern pollen samples, pristine conifer forest, Ural Mountains

\section{Introduction}

Investigation of modern pollen-vegetation relationships is crucial for correct reconstruction of past vegetation from pollen profiles (Overpeck et al. 1985; Sugita et al. 2010). Pollen productivity is one of the key parameters in those relationships (Gaillard et al. 2008). This study is an attempt to evaluate modern pollen-vegetation relationships in the pristine dark coniferous forest and to produce reliable pollen productivity estimates (PPEs) as a contribution to palaeoecological research. Modern pollen spectra from western slope of Northern Ural have been poorly studied. Most of already published modern pollen data were collected in Southern (Lapteva 2005, 2007) and Polar (Jankovska 2007) Ural. This research has been made with aims to 1) investigate how modern pollen assemblages from western slope of Ural Mountains reflect surrounding landscapes and to 2) produce the new set of PPEs reliable for that particular area.

\section{Study area}

The study area is located in the piedmont of Pechora-Ilych Nature Reserve (south-eastern part of Komi republic, Russia), on the western side of Northern Ural Mountains. The region is dominated by forests of shade-loving species: $\mathrm{Si}$ berian spruce (Picea abovata Ledeb.), Siberian pine (Pinus sibirica Du Tour), and Siberian fir (Abies sibirica Ledeb.). Birch (Betula pubescence Ehrh.) is growing in stands as 
an admixture. Singular rowan trees (Sorbus aucuparia L.) sprout in rich forest types (Korchagin 1940). Old-growth and uneven-aged dark coniferous forests occur all over the area except small patches of bogs and meadows in the floodplain of the Bolshaya Porozhnaya river. The Pechora-Ilych Biosphere Nature Reserve in the Ural Mountains is considered to be the most undisturbed taiga in European Russia. The vegetation and forest structure show no visible traces of human impact for at least two full tree life cycles (ca. 500 years) (Aleynikov et al. 2015).

The study site located in a couple of kilometers to the north of the influx of the Bolshaya Porozhnyaya river to the Pechora river.

\section{Method}

33 modern surface samples (Sphagnum mosses, green mosses, litter) were collected by random sampling in all vegetation formations (several types of dark coniferous forests, mires, meadows in the river floodplain) in June 2016. The samples were collected with aim to accumulate several years of pollen loading: depth and the surface size of the sample were recorded in the field (Lisitsyna \& Hicks 2014). Most of samples are collected under the forest canopy with opening of less than 1 ha. At all points, detail vegetation descriptions within $1 \mathrm{~m}$ radius, as well as within $400 \mathrm{~m}^{2}$ were performed along with samples collection. Vegetation mapping was conducted in the whole investigated area. Laboratory preparation of the surface samples followed standard procedures. The pollen was counted at 400x magnification until a sum of 500 arboreal pollen grains (AP) was reached. Pollen and spore identification was based on Moore et al. (1991).

\section{Results and discussion}

Forest vegetation of that area mainly belongs to four sections: Sphagnum, true moss, tall fern and tall herbs sections (Smirnov 2013). All modern pollen spectra are rich by tree pollen with dominance of Betula (40-50\%), Pinus haploxylon (30\%), Picea (17-22\%). Small proportion of Abies (3-4\%) and Alnus (0.1-2\%) pollen was detected in surface samples. Microcharcoal particles were found in amount $4-8 \%$ from total pollen sum. They are clearly detect local forest fire of 2004 located within $3.5 \mathrm{~km}$ from sampling points (Tinner 2006). The pollen grains of ferns (Dryopteris type, Gymnocarpium type), herb plants (Poaceae, Ranunculus type, Cyperaceae, Acteraceae, Rosaceae) and dwarf shrubs (Ericaceae) are also present in modern spectra.

The pollen assemblages and vegetation data will be analyzed by numerical methods (clustering and correspond- ence analysis) to investigate how vegetation is reflected in pollen assemblages. The PPEs for the most common species in that area will be produced using that set of modern samples with help of Prentice-Sugita model (Prentice \& Parsons 1983; Sugita 2007a, b). The PPEs for major western and central European species form different natural zones has been already produced (Broström et al. 2008; Poska et al. 2011; Abraham \& Kozakova 2012). Those PPEs are now in use for reconstructions of vegetation, landscapes and climate of the past of the origin area. However the application of PPE value for different vegetation and climatic zones questionable (Abraham \& Kozakova 2012). Therefore the investigation of modern pollen-vegetation relationships in parental vegetation zone is crucial for correct reconstruction of past vegetation from pollen profiles. The dataset presented will be also used for the interpretation of the fossil pollen profile from the Bananbog (located in the middle of study area) taken in 2011.

\section{Acknowledgements}

The study is supported by Russian Foundation for Basic Research (RFBR projects №15-34-20967, № 16-04-00395, and № 17-04-01034).

\section{References:}

Abraham V. \& Kozakova R., 2012, Relative pollen productivity estimates in the modern agricultural landscape of Central Bohemia (Czech Republic), Review of Palaeobotany and Palynology 179(0): 1-12.

Aleynikov A.A., Tyurin A.V., Simakin L.V., Efimenko A.S. \& Laznikov A.A., 2015, Fire history of dark needle coniferous forests in Pechora-Ilych nature reserve since second half of XIX century to present time, Sibirskij Lesnoj Zhurnal (Siberian Journal of Forest Science) 6: 31-42 (in Russian with English abstract).

Broström A., Nielsen, A.B., Gaillard M.-J., Hjelle K., Mazier Fl., Binney H., Bunting J., Fyfe R., Meltsov V., Poska A., Räsänen S., Soepboer W., von Stedingk H., Suutari H. \& Sugita S., 2008, Pollen productivity estimates of key European plant taxa for quantitative reconstruction of past vegetation: a review, Vegetation history and archaebotany 17: 461-478.

Gaillard M.-J., Sugita S., Bunting M.J., Middleton R., Broström A., Caseldine C., Giesecke T., Hellman S.E.V., Hicks S., Hjelle K., Langdon C., Nielsen A.-B., Poska A., von Stedingk H., Veski S. \& PolLandCal members, 2008, The use of modeling and simulation approach in reconstructing past landscapes from fossil pollen data: a review and results from the POLLANDCAL network, Vegetation History and Archaeobotany 17: 419-443. 
Jankovska V., 2007, Composition of pollen spectra from surface samples produced by present-day vegetation of boreal zone Eastern from Polar Ural Mts. (Russia), Pollen Monitoring Program, volume of abstract, $6^{\text {th }}$ international meeting 3-9 June 2007, Jurmala, Latvia: 29-31.

Korchagin, A.A., 1940, The vegetation of northern part of Pechora-Ilych nature reserve. Proceedings of PechoraIlych nature reserve 2, (in Russian).

Lapteva E.G., 2007, Vegetation and climate development on eastern slope of Ural mountains in the last half of Late Pleistocene and Holocene, thesis summary, Moscow.

Lapteva, E.G., 2005, Comparison of subfossil pollen spectra with modern vegetation of the midle and southern Ural mountains, $11^{\text {th }}$ All Russian conference "Palinology: theory and practice", 27.09-1.10, 2005, Moscow, conference materials: $126-127$.

Lisitsyna O.V. \& Hicks S., 2014, Estimation of pollen deposition time-span in moss polsters with the aid of annual pollen accumulation values from pollen traps, Grana 53: 232-248.

Moore P.D., Webb J.A. \& Collinson M.E., 1991, Pollen analysis, 2nd edn., Blackwell Scientific, Oxford.

Overpeck, J. T., T. Webb III. \& Prentice I. C., 1985, Quantitative interpretation of fossil pollen spectra: Dissimilarity coefficients and the method of modern analogs, Quaternary Research 23: 87-108.

Poska A., Meltsov V., Sugita S. \& Vassiljev J., 2011, "Relative pollen productivity estimates of major anemophil- ous taxa and relevant source area of pollen in a cultural landscape of the hemi-boreal forest zone (Estonia)., Review of Palaeobotany and Palynology 167(1-2): 10-10.

Prentice I. C. \& Parsons R. W., 1983, Maximum likelihood linear calibration of pollen spectra in terms of forest composition, Biometrics 39: 1051-1057.

Smirnov N.S., 2013, Typological and Species Diversity of Dark Conifer Forests in the Lower Reaches of the Bol'shaya Porozhnyaya River, a Tributary of the Pechora (Pechora-Ilych State Nature Reserve), Russian Journal of Ecology (1): 28-35

Sugita S., 2007a, Theory of quantitative reconstructions of vegetation I: pollen from large sites REVEALS regional vegetation composition, The Holocene 17(2): 229-241.

Sugita S., 2007b, Theory of quantitative reconstructions of vegetation II: all you need is LOVE, The Holocene 17(2): 243-257.

Sugita S., Parshall T, Calcote R. \& Walker K., 2010, Testing the Landscape Reconstruction Algorithm for spatially explicit reconstruction of vegetation in northern Michigan and Wisconsin, Quaternary Research 74(2): 289-300.

Tinner W., Hofstetter S., Zeugin F., Conedera M., Whohlgemuth T., Zimmermann L. \& Zweifel R., 2006, Longdistance transport of macroscopic charcoal by an intensive crown fire in the Swiss Alps - implications for fire history reconstruction, The Holocene 16(2): 287-292. 